\title{
Failures in Decolonization and 'the Return to the Past': Reading V.S. Naipaul
}

\section{Mahesh Hapugoda}

Department of Languages, Faculty of Social Sciences and Languages,Sabaragamuwa University of Sri Lanka. hapugoda@gmail.com

\begin{abstract}
This study examines the failures in decolonization and its political outcomes leading to a phenomenon called 'totalitarianism' in a transitional post-colonial context, as characterized in the works of V.S. Naipaul. It attempts to articulate how the postcolonial nations, once 'abandoned' by their Colonial Masters and then taken over by unsuccessful indigenous rulers, have encountered symptomatic political development within themselves 'as finite limitations of their existence' as they have emerged and are ideologically embedded in a historically affected consciousness (Gadamer 2006). To escape from the humiliation, dislocation, anxiety, jealousies and alienation generated by modern secularism and rationalism transmitted through colonialism itself, they seem to 'return' (Amin 2014: 81) to an ideology largely borrowed from history and tradition as 'retrogressive nostalgia' for today's and tomorrow's problems, which ultimately results in nothing but violent totalitarianism. In such transitional contexts where societies still struggle to come to terms with modernity, though the material conditions of life improved, the shift in mentality (Miao 2000) from one condition to a completely unprepared and unexpected phase remains crucial. The destructive energy that is often used against the universal civilizing force is seen here as a 'compensation for the pain suffered through the disintegration of traditional forms of live' (Habermas 2007: 102). This study, with the support of contemporary philosophical, political, literary and psychoanalytical interventions, dialectically examines how such symptomatic developments are empirically explored in the fictional and biographical works by V.S. Naipaul.
\end{abstract}

Keywords: Naipaul, decolonization, totalitarianism, transitional societies

\section{Introduction}

The aim of this study is to interpret and contextualize selective works of V.S. Naipaul in the social transformation process called decolonization. When the colonized societies transform from tradition to modern, I argue, that the failed project of decolonization drives the colonized subjects to 'return' to 
the ideological comfort of the tradition instead of generating modern secular individuals. This study observes, as evidenced in the works of Naipaul, that the humiliation, dislocation, anxiety and jealousies towards the luxuries of modern secularism have made the colonized subjects to violently respond to modernity by traumatizing the existing life-world. This trend has destroyed the democratic public sphere of the colonized nations and given way to a racist form of nationalism by 'negating the social life itself, the erosion of its foundation' (Hardt and Negri 2000: 113). Most importantly, when the traditional societies co-exist with their pre-modern values and fight against "westernized" modernity and secularism 'by means of pre-political traditional religious form of protest' (Zizek 2014: 281), I argue, against Chakrabarty (2000), that the archaic traditional ideologies and practices themselves stand anti-progressive in terms of universal emancipatory politics. Therein, Naipaul's Eurocentric perspective, amidst lot of criticisms, of societies who 'torn between modernism and the return to tradition' proximates more towards remaining 'faithful to the universal/secular project of modernity'(Zizek 2014: 280).In that light, Chakrabarty's idea of 'organic unity' within a society without any periodical historical progress or universal standards of historical stages and the denial of "incompleteness" of pre-modern political practices has to be contested in the light of empirical evidence cited by Naipaul.

The contemporary decolonization ${ }^{l}$ process has, because of its own limitations, to a large degree, failed to generate an advanced cognitive space where individuals make rational judgments about their life world. Hence, higher judgements taken independently with conceptual and discursive capacities, enhancing individual's cognitive potential to 'reject everything that was not true, not justified by free reason' (Marcuse 1998: 43) was not to be seen or practised in a majority of postcolonial contexts (especially those with serious ethno-political divisions coupled with geographical sensitiveness) as in advanced Liberalist societies. Though the western societies too experience anti-Enlightenment tendencies within their historical development especially in the twentieth century and are subject to confront with the rise of religious reason (Rawls 1997; Audi 1993; Habermas 1981 and 2006), the nature and the intensity of the crisis generated by religious ideologies derived from tradition seem more serious, politicized and threatening in the colonized nations. In the west, it is often believed, that the death of reason and the rise of authoritarianism may last for a brief period and then the system will be back to normal. Contrarily, some of the post-colonial nations may not see the end of ultra-nationalistic fundamentalism for a long time. Under these contexts, it is observed that the rational reasoning is taken over by inherent organic biases in traditional ideology instigated by myths, chronicles and historical interpretations, and anything that does not fit into this framework of thinking and practising or hurts the sentiments of the traditionalist is negated, 
looked down upon or sometimes leads to punishments of barbaric nature in its extremes.

The anti-enlightenment tendencies in the once colonized world are thwarting the logic of universalism in favour of traditionalism. With tremendous politicomilitant power and ideological backing, at the moment, these 'organic' societies are determined to destroy all that is western, secular and modern and, at least in the ideological frontiers, it is deemed a scholarly responsibility today to save the classical antiquity and its enlightening potential to set the world free from its esoteric forms (Habermas 1981: 9) at some future point. In this historical juncture, turn to Naipaul for literary evidence to identify the vulnerable identity issues of the colonial subjects is not coincidental. V.S. Naipaul is acknowledged as an author who initially wanted to move away from the limited colonized world to the metropolitan that offered him 'the idea of our modernity and development' (Naipaul 1979, 2002: 269). Because of his geographical drift and not-belonging sense, he became a writer who effectively used the insider-outsider point of view to understand and express 'the larger truth through not being partisan' (Park 1996: 243). Of those who truly and objectively capitalized on the anarchical and nihilistic aspect of the 'transitional and makeshift' (Naipaul 1967, 2002: 6) postcolonial societies where serious identity issues have created deeper socio-political calamities, V.S. Naipaul unarguably emerged as a pioneer.

In this context, this discussion puts together two significant literary and ideological developments the twentieth century. To analyse V.S. Naipaul in the context of decolonization, this reading will primarily draw literary evidence from Naipaul's works over the events in the transitional postcolonial world and, secondarily, those evidence would be interpreted in the light of contemporarily politico- philosophical interpretations about a.) decolonization and post-colonialism (Fanon 1963 and 1964; Amin 1994 and 2014; Kellner 2002; Ahmed 2004; Hardt and Negri 2001; Khan 2012) and b.) the rise of totalitarianism (Arendt 1951, Marcuse 1998, Sharpe and Boucher 2010, Zizek 2002, 2005, 2008, 2011 and 2014) . In this study, a re-reading to Naipaul's literary journey is proposed to contextualize the failed project of decolonization, from the return to tradition to the rise of totalitarianism developed from within dialectic coordinates of modernity itself. This contextualization would first identify the evidence about how the decolonization process took place in the third world as depicted in the selective work by Naipaul. Based on fictional evidence by Naipaul, together with different responses given by contemporary literary critics, this study attempts to theorize that the anxiety, dislocation and the jealousies towards modern secularism drive the deprived and alienated colonized subjects to the ideological comfort of history, past or tradition, and most dangerously, such subjects re-emerge to the present with barbaric violence as a primary response against 'westernized' modernity. 
However, since this paper is extracted as part of an extended study on V.S. Naipaul, the entire discussion is narrowed down to two major aspects. As objectives, it aims,

a. To investigate how the subjects in postcolonial transitional societies have shown post-independent symptoms of subjugation by 'returning' to tradition and indulging in a 'deceptive mental comfort' as an entity of security and how they violently try to 're-establish' the archaic values of a fantasised past and enforce on the others to accept. The kind of education practised under colonialism and ever afterwards did not 'prepare' the individuals who emerged from tradition and feudalism, or 'stand out' in inculcating the cognitive capacities to 're-negotiate the meaning in time' (Bauman 2011:2). The above deficiency similarly applies to the failure in the political agencies as well at that time, and Naipaul's writings bear constant evidence in this regard. This paper identifies the said feature as a failure in the decolonization process and brings in evidence from selected literary works by Naipaul. In doing so, it is intended to display how such failure results in symptomatic totalitarian development within transitional social contexts auxiliary helping to theorise the contemporary dictatorial political developments in the postcolonial world.

$b$. To briefly identify how the short-sighted political strategies exploited in the decolonized societies in 'regaining past' give way to ideologically strengthen the fundamentalist totalitarianism. It reveals the potential danger in the 'organic-ness' that seeks the nostalgic historical fantasy 'to regain a puritan past' is often connected to discursive political developments such as radicalization or nationalization as shown in Naipaul's writings.

\section{The Failed Project of Decolonization}

Liberal capitalism has been the main force in changing the traditional form of life during and after imperialism and introducing modernization of the lifeworld of the traditional communities. Capitalism, because of its undeniable progressive function towards 'the development of the forces of production' and associating it with an 'equitable distribution of income' (Amin 2013: 2) stands as the sole agent of legitimate economic order today. Hence, it is more than an economic system but 'a higher stage in the development of human civilization' (2). The secular education under imperialism brought about significant changes to traditional way of thinking but the way it was implemented in the colonial world had serious limitations both in relation to its mutually inclusively objectives and outcomes. Since missionary education did not have a grand plan and it was fragmented and contradictory, colonial education was 'limited to a basic elementary level-extending no further than the transmission of minimal literacy and numeracy skill' (Paisley and Reid 
2014: 9) The colonial master wanted a kind of 'literate' social layer whose members can be employed for their subordinate minor-administrative works. It was not part of the Enlightenment project where free individuals are supposed to use their critical thoughts and analytical skills for the advancement of the existing status quo on larger systemic scale. After the imperialist stage of capitalism, as we know, the expansion of liberalized economic forces leads to create globalization. Even globalization, the next advanced stage of capitalism, was not meant not encompass 'everything' in those societies but it only united the market forces, creating profound inequalities (Bauman 2000; Stiglitz 2002; Amin 1998, 2013; Dierckxsens 2000). The marginalized and unprivileged segment generated by globalized capital started reacting to its forces that widened divisions and inequalities. The violent reaction to modernism promoted under globalization emerges from the deprivation and disappointment of the underprivileged. The systemic failure of capitalism undoubtedly reflexes in the failure of decolonization process.

The failure of the neo-liberal model of globalization is also attributed to the phenomenon called neo-feudalism ${ }^{2}$ that springs up mostly in the third world. Despite the limitless authority of capital and globalized culture propagated through the market forces, the feudal system that is still remaining in the transitional societies rejuvenated to foster anti-democratic and neo-fascist movements. Historically, the origin of economic anti-democratic trend, as Dierckxsens (1998) observes, sprung up from within the market crisis in liberalism. He points out,

Liberalism hit bottom during the crisis of the 1930s with the stock market crash and the ruin of many companies. Since it was no longer useful to the bourgeoisie it was substituted by nationalist protectionism. Corporate, authoritarian and anti-democratic state power was born, based on the same atomizing individualism that characterized economic liberalism (1998:120).

The manner in which capitalism expanded across the globe after the Second World War or application of the logic of capitalism threatened 'the national systems of production created by the previous historical period' (Amin 1998:16). Under the new system, global production and the market grew across the boarders and forced the peripheral nations to re-structure their political systems to match with the new inflow of capital. The novel 'networked society' and the universalization of consumerism 'supplanted the local cultures and traditions' (Kellner 2002: 285) which means that the cultures that existed within certain geographical boarders happened to make way the new global culture. More than the direct methods used under imperialism, local communities came across quick and radical changes which completely uprooted the traditional world order and its values. Unlike under colonial imperialism, the intensity to introduce material secular values desired by global 
consumerism was profound, empathic and unavoidable. The interpretations proposed to individuals by tradition were no longer applicable to complex brand new situations and 'the historical narratives appeared outdated and illegitimate' (Hennayake 2006: 80).

Global Capitalism not only challenged traditionalism but almost all the principle values cultivated by modernism itself. As Hardt and Negri observe, this new empire constitutes 'a new planetary order' and 'we are confronted no longer with the local mediations of the universal but with the concrete universal itself' (2000: 19). They also point out, 'it deploys a powerful police function against the barbarians and the rebellious slaves who threaten its order' (20), and the marginalized segments from which those rebels and slaves were originated during the previous system both under the colonial and decolonial processes were further alienated by the new. Those who did not or reluctant to acquire necessary skills to survive under the new inflow of liquidated capital became 'outcastes' who then relied on the fantasy of historical narratives to ideologically defend their existence and radical function against the new enemy. Two historical phenomena, the dissolution of local culture in the face of new universalism and the insecurity of consumer secularism unexpectedly merged as pre-modernism and post-modernism; both collectively stood to fight the spirit of modernism. The loss of legitimacy in traditionalism is compensated through the collapse of meta-narratives (loss of master signifier) in the postmodern era.

\section{'The Return to the Past' and the Rise of Totalitarianism}

'The return to the past' is more than a simple nostalgic revisit to an idealized past for psychological comfort; ideologically, is a political process where subjects in transitional contexts try to violently 're-emerge' to the present and materialize the past. The end result of this ideological attempt demands total submission and tolerance of individuals during the process to regain the lost superiority of the past. In other words, such anti-democratic movement totalizes or taking the total control of every aspect of social life of an individual, be it economical at a macro basis or socio-cultural in a micro level. Even though Arendt (1951) observes that threats and demands of a totalitarian ${ }^{3}$ regime are $^{-}$ mostly indirect and veiled, the barbaric and banal form of fundamentalist totalitarianism today functions in a very obvious manner. It insists more on cultural submission than political obedience; the latter is often taken care from an ultra-military mode. It manipulates a sort of 'eternal laws of nature and life' (Arendt 1951) in an urgency with missing the train of history on individuals if they do not right now partake in the collective utopia of the ideology. If not, it will be an irreparable and mysterious deterioration of a historical heritage, bloodline or totemic religious legacy. By completely taking cultural life of an 
individual over to its hands, generally, totalitarian regimes sadistically employ violence to maintain complete obedience, de-moralize democratic institutes and to make their authority beyond questioning. Rational thinking ceases to exist when one truly begins to suspect or query the very foundation of the totalitarian ideology and its functions. Hence, the faculty of thinking based on reason, judgements based on rational understanding and critical evaluation, search for truth and more evidence; in short, the whole exercise of scholarly opinion is directly or indirectly either prohibited or largely discouraged.

Totalitarianism, in its broader sense, is a phenomenon where 'banality of evil has accentuated the whole relationship among the faculty of thinking, the capacity to distinguish between right and wrong, the faculty of judgement, and their moral implications' (Assy 1996:1). But the similarity can be drawn between the two when the unquestioning subjugation of individuals to the infinite authority and its use of terror against freedom and democracy in a society take place by silently tolerating or neglecting the obvious reality of suppression. The individuals cynically and ritualistically maintain an inner-distance toward the total manipulation of the entire social process and rationalizing such manipulation (Zizek 2002). In short, it is the suppression of public use of reason by hystericizing the crowd 'to hold them in obedience with a mixture of threat and promise' (244). However, in both occasions, such totalizing potential is derived and shared from a single Ego Ideal in the name of a king (Sharpe and Boucher 2010).

Trends which emerged in post-colonial nations are often termed as 'antimodernist movements, resurgences of primordial identities and values' and 'can be conceived as a kind of historical backflow, a de-modernization' (Hardt and Negri 2000: 146). Presently, the religious revival and its fundamentalist movement in challenging modern secularism and rationalism can even be evidenced in Western civilizations 'washing away or at least levelling the thresholds hitherto assumed to pertain between tradition and modern societies' (Habermas 2006: 2). Hence, Habermas attributes the rise of fundamentalism to the 'long-term impact of violent colonization and failures in decolonization' (2006:1). On this phenomenon, further he notes,

'Under unfavourable circumstances, capitalist modernization penetrating these societies from the outside then triggers social uncertainty and cultural upheavals' (2006:1).

The state of returning to the remnants of the past and to the comfort of tradition and its organic evil is also reviewed in Stavrakakis' Lacan and the Political as a phenomena resulted from the 'dislocation of traditional forms of organizing and making sense of society, a dislocation inflicted by the increased hegemony of secularism, liberalism, socialism and industrialization' (1999: 103). The 
impact that the mega social projects in the modern civilization such as global form of liberal capitalism and socialism in the first half of the twentieth century had on traditional and post-colonial nations was immensely powerful and, subsequently, created serious rivalries, marginalization and polarizations (Fanon 1963; Wallerstein 1974; Amin 1994; Huntington 1996; Kellner 2002; Ahmed 2004). At the same time, as McLuhan (2001) observes the luxuries of modern secularism in the west generated anxieties and jealousies in those who could not materialise them. Therefore, both marginalization and jealousies in the transitional ${ }^{4}$ traditional societies generated deep divisions between modern secularism and traditional world views while generating violent reactions towards secular nations.

The post-colonial subjects are exposed to the false ideology of some kind of 'perfect final stage of mankind' (Sharpe and Boucher 2010, 94) such as Aryan domination or the dictatorship of the proletariat. Even the nostalgia of some historical heritage or blood line can effectively fit into this false ideology. In this regard, the fascists gained support from the established aristocratic and business classes to successfully function as 'reactionary-modernist' regimes and were able to manipulate the most developed modern media, industrial and military technology to reach their target. As observed by Sharper and Boucher,

However, fascism is predicated on a reactionary criticism of the decadence or 'nihilism' of liberal society, and the way that the intrinsic dynamics of capitalist economies breaks up traditional, organic, racially and culturally unified communities $(2010,95)$.

The above reason indicated by Sharpe and Boucher forms the main bedrock for creating one of the greatest paradoxes that the postcolonial nations have to live with until today, i.e. broken up traditional societies arise as reactionary fundamentalist to the secular tendencies of liberal capitalism from within the coordinates of liberal capitalism itself . This trend has historically challenged, through its physical energy, and is trying to destroy the only and the most sustainable 'changing agent' of modernity. During and after long stages of imperialistic capitalism, now that the globally expanding mercantile capital at its advanced stage (Amin 2013), modern education introduced by the imperialists, with grievous limitations, still remains the 'changing agent' for developing nations (most of the postcolonial states included). As Ziltener and Kunzler (2013) correctly observe, the missionary education, modern health care, judicial system, democracy, technology, transportation, commercial agriculture, new social structures including new economic models and market places etc created a new social world for traditional communities and freed them from their bondage to caste, gender and mystery. Hence, if the concept 'decolonization ${ }^{5}$ means something more than biophysical and is supposed to 
re-construct the relationship between meaning and the constitution of forms of life, the danger of subordination of individual to futile conditions of meaning should be carefully avoided (Gordon 2010: 9). But the empirical evidence today witness that those who were liberated from the chains of Colonial Masters have surrendered again to the call of irrational violence and totalitarianism by ideologically returning (Amin 2012) to tradition and its organic bias. To explore the above socio-political situation, the evidence found in the works by V.S. Naipaul would be of substantial significance.

\section{Naipaul in the Failed Project of Decolonization}

The existing literature about the works of V.S. Naipaul basically falls into two main categories. First, the majority of available literature is about literary criticism which articulates common post-colonial themes such as alienation, exploitation and identity crisis of the once colonized subjects (Singh 2013; Park 1996; Harode 2012) while some others critically concentrate how the colonial people 'entangled' in the western form of modernity and secularism in his works (Cader 2008; Singh 2006). The other category, small in number, is critical about Naipaul's Westernized world view towards the post-colonial socio-political and cultural developments (Said 1993 and 1986; Bhabha 1985; Eid 2000; Johnstone 1979; Cudjoe 1988). These two categories, though sufficiently talk about the impact of colonialism on indigenous cultures and the implications of decolonization, do not pay significant attention to how 'the ideological returning to the organic biases of the past or tradition' bring about violent repercussions on the present moment of existence. By looking at the fundamentalist tendencies in the post-colonial world today, the situation has been much more serious and dangerous than what Naipaul prophesied during his days few decades back. So, it is deemed that a re-reading of his works is much needed in the present context.

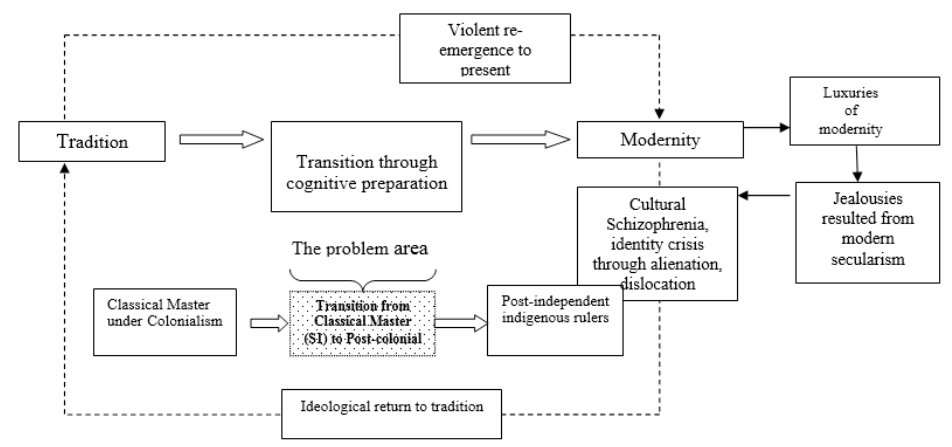

Figure 01: Ideological Return to Tradition

Source: Author 
The above Figure 01 illustrates how the anxious and schizophrenic postcolonial subjects ideologically 'return' to the past for psychological comfort. They return to the false discursive comfort of the traditional past. This creates an emergence of a violent return of the tradition which eagerly tries to compensate for its lost glory. This 'return' has been, as we experience today, excessively violent and there is no end to its revenge from modern rationality. It is in this conjuncture that this study contextualizes V.S. Naipaul as a writer who bears witness to the above misadventure of modern post-colonial man.

Under post-colonial literature, the failure in the process of decolonization is evidence in many contemporary writers such as Chinua Achebe, Salman Rushdie, Wole Soyinka, Arundhati Roy, Bapsi Sidhwa, Shyam Selvadurai and many others, but V.S. Naipaul digs deep into the Asian Feudal hierarchy in his large number of fictions and non-fictions over a time span of fifty years. Despite criticism about his male-chauvinism (Mohan 2004) and celebration of the 'triumph of colonialist moment' (Bhabha 1985), Naipaul has succeeded in depicting a postcolonial reality that kept on failing in building a righteous society of universal emancipation (oriented towards the ideals of truth, freedom and justice) through reasonable application of Law and Order. Despite his western orientation, he is 'ruthlessly honest' (Said 1993: 19) in portraying the objective side of the colonial and decolonizing projects. Some of his works, as observed by Sudipta Chakraborty, obviously progress from the glamourization of west towards 'the exploration of alternative spaces of modernity and belonging (2011: 26). While the dominance of colonial ideology and 'the imposition of British colonialist-imperialist values upon colonial people' (Cudjoe 1988: 58) are commonly visible in his works, Naipaul's writing truthfully articulates 'the impact of imperialism on the life and personality of the colonized individuals' (Harode 2012: 3). In his wide range of independent writings in analysing and interpreting his own past and experiences for five decades, he could produce some sort of compilation of spiritual and psychological autobiography. As a result, comparisons across texts are possible and social evolution can subsequently be traced. Similarly, examining the irrational political domination in the light of 'the substitution of theology for education and suppression of all individuality' (Feder 2001: 135) can also be areas of research interest for examination.

There are significant features that distinguish Naipaul from other contemporaries and make him perhaps the most appropriate in the context of this research. Throughout his works Naipaul maintains an insider-outsider point of view. He favours the rational secular motives of the colonization project while objectively illustrating the catastrophic elements within it. He fearlessly discloses the imperialistic motives of the colonial masters in a very dialectical manner which reminds us of a very popular statement once made by Walter Benjamin, 'there is no document of civilization which is not at the 
same time a document of barbarism'(1969:256). Naipaul, in his famous novel, $A$ Bend in the River (2002) mentions,

But the Europeans could do one thing and say something quite different; and they could act in this way because they had an idea of what they owed to their civilization. It was their great advantage over us. The Europeans wanted gold and slaves, like everybody else; but at the same time they wanted statues put up to themselves as people who had done good things for the slaves. Being an intelligent and energetic people, and at the peak of their powers, they could express both sides of their civilization; and they got both the slaves and statues (19).

If modernism is meant to break from the past (Rutherford 2006) and its metaphysical, mythical and traditional teachings, Naipaul too advocates a serious deviation from our identifying with it. Naipaul clearly maintains the stand that one has to be unchained from his or her ancestral history to move forward. He once mentioned, 'To be converted you have to destroy your past, destroy your history. You have to stamp on it, you have to say 'my ancestral culture does not exist, it does not matter' (as cited in Khan 2009: 172). This perspective that he has apparently used in his works is extremely useful for a study that interprets the social transition process seen in his writings from tradition to modern in a dialectic sense. With his split identity and the sense of not belonging to anywhere have made him unbiased to any particular history of any nation that he happened to live or encounter. In this way he has become an important witness to the disintegration, ingenuity and inauthenticity of the third world ${ }^{6}$.

As a writer of international reception and a Nobel Laureate, having won numerous awards on his contribution to literature, V.S. Naipaul's works bear much elaborated empirical evidence about the post-colonial societies in transition. To understand him more, it is important to understand his social setting in which he was brought up. When he was born in Trinidad, it was a British colony which was comprised of a population of majority of Africans descended from slaves and 'a large minority of Indians, descended from indentured laborers who were imported to replace the slaves when slavery was officially abolished in the British Empire' (Dooley 2006. 2). His exposure to Africans as well as people of Indian origin in a very early stage of his life has made a tremendous impact over his world view reflected in works. However, he was writer who actually 'disenchanted by his past and his native background' (Deodat 1979: iv). He recognized his inability to become part of the Trinidad society when he was eleven. In the meantime, Naipaul saw his own scholarly potential in the early stage of his life and was trying to make an exit from the small world that he happened to be born. As Dooley notes, 'from an early stage saw the possibility this [his scholarly ability] provided 
of escaping from the limited society of Trinidad to the "real" world aboard' (2006.2). As true for any postcolonial subject, this shows the nature of postcolonial psychological dilemma which he was struggling with in the early stage of his life. He used to think that colonial cultures are trapped by their own histories, practices, biases and traditions.

In his works Naipaul illustrates the cultural dilemmas of the colonized nations who are caught between their powerful historical narrations and traditions based on those narrations and modernization. Though Naipaul talks about this complex and conflicting interrelationship between tradition and modernity, he did not particularly belong to either camp. He has been an 'observer rather than participant, the witness who describes but not prescribes' (Johnstone 1979: 108). In this context, therefore, the themes that come out from his works are essentially complex and critical. It is the chaotic nature of the experience of these colonial nations that makes Naipaul's realism a unique one. According to Bruce King,

Besides the complexity of characterization and the mixture of criticism with sympathetic understanding, there is often a profound substrata of literary and cultural associations giving Naipaul's realism, and social and psychological analysis, roots in history, archetypes, myths and symbols (2003: 202).

The time and setting of his works mostly relate to post-independent periods of those societies and, in other words, this is the era of decolonization which I try to examine in my study. In this case, I intend to further the psychoanalytical significance of his thematic observations that extends to colonization, alienation, dislocation, hybrid identity and, most importantly, the failures of the western secular values in the colonized third world. As observed by many critiques, the indigenous communities experience a major psychological breakdown due to the dislocation and identity crisis incurred to them by the imposition of two totally dissimilar and incompatible worlds. This situation is further illustrated by Reeta Harode (2012) in her article 'Postcolonial chaos in V.S. Naipaul's Mimic Men';

The natives who are devoid of their own cultures, customs and traditions, religions, and race consider themselves to be inferior to those of their masters and try to identify themselves with the empire. As they are far away from their original homeland, their own original traditions and religions have become meaningless to them and being completely different from the master in cultural, traditional, racial and religious backgrounds, they can never successfully associate themselves with the colonized other. They suffer from dislocation, placelessness, fragmentation, and loss of identity. As these psychological problems remain unsolved even after independence is achieved, independence itself becomes a word but not a real experience. Without the colonizer, the 
colonized see themselves as loss in their postcolonial society that fails to offer a sense of national unity and identity (2012: 7).

The in-betweenness or not belonging either to traditional way of life or secular modernity has caused a kind of psychological paralysis in the colonial subjects. In spite of living in a modern life with individual freedom, secular values and democracy, the colonial people live a life of ambivalence (Noor 2013). The reason why Naipaul should be studied in the above context of psychological dilemma, paralysis and disorder is that he 'goes beyond the bounds of regionalism and also avoids the trap of nationalism' (Park 1996: 181) and observes this phenomenon as an outsider. His expatriate writing career was largely unaffected by the popular political developments of his time, his vision was his own and may be the reason why he has been criticized by many literary and political critics (Said 1986; Johnstone 1979; Eid 2000) Therefore, some of the themes that Naipaul brings out appear for the first time in the postcolonial literature. As Champa Rao Mohan points out,

The themes of alienation, homelessness and mimicry still preoccupy Naipaul but the perspective has changed. They are now viewed as a universal condition of the modern world afflicting both colonized and colonizers alike. Besides the familiar themes that still haunts Naipaul's pen, there are themes that appear for the first time- the broader post-colonial themes of power and freedom and neocolonialism (2004: 81).

The psychology of the colonized people and how they respond to the postcolonial situation was significantly depicted in the novel 'The Mimic Men' $(1967,2002)$. As Naipaul puts it, 'The empires of our time were short-lived, but they have altered the world for ever; their passing away is their least significant feature' (2002: 32). This very statement evidences the enormous changes that the colonial master brought to the indigenous world and irreversible changes took place in this part of the world. As a writer, Naipaul was actually trying to understand this confusing and profound social transformation and respond to it in his own way. He writes,

'It was during this time, as I have said, that I thought of writing. It was my hope to give expression to the restlessness, the deep disorder, which the great explorations, the overthrow in three continents of established social organizations, unnatural bringing together of people who could achieve fulfilment only within the security of their own societies and the landscape hymned by their ancestors, it was my hope to give partial expression to the restlessness which this great upheaval has brought about' (32).

Naipaul perceives the process of colonization and the political changes after independence as waves of history which kept on changing the way of life. In the novel $A$ Bend in the River $(1979,2002)$ he mentions, 'We had lived 
our lives in our way, done what we had to do, worshipped Gods and obeyed his commandments. Now- to echo Indar's words- another tide of history was coming to wash us away' (Naipaul 2002: 22). For the postcolonial world, the life styles, beliefs, practices, ideologies, political structures and mode of authority and power shifted from one master to another in quick succession; from the traditional indigenous masters to colonial and then back to the indigenous. For the above transformation to happen, it took about a period of two centuries maximum. As far as the modern structural changes are concerned, these two centuries may be the most influential period of the present social fabric of these postcolonial nations. Most importantly, these structural changes altered the way of our thinking. Naipaul considered those changes as true force of history and the 'western civilization' is 'really a universal civilization based on the rights and responsibilities of the individual' (Mohan 2006: 69).

\section{From the Classical Master to the Irrational Dictator}

The sustaining ideological fantasy produced by the Discourse of the Master (S1) is that such master is the bearer of a 'second body' which carries the sublime object of ideology. In other words, in him, it was believed by the subjects, there is more than himself. May be, as a King, for an examples, people believed that he is made of some 'special stuff' derived from some hereditary which gives him a special right to rule?

Such ruler uses his sublime-ideological mandate in this discourse as an accorded special, even sublime authority (Sharpe and Boucher 2010, 92).

Sometimes, it may be royal blood that gives the necessary justification for such ruler to be unique amongst the ordinary or elevate above the ordinary (as claimed by Bokassa in Opera Wonyosi that he too carries 'the blood of the Kings' and 'not ordinary' (Soyinka, 2009)).

Traditional authority was based on what we could call the mystique of the institution. Authority based on its charismatic power on symbolic ritual, on the form of the Institution as such...(Zizek 2007, 249).

The liberal- bourgeois principle of rational authority is transformed to irrational and unconditional authority in the post-liberal totalitarian context. In other words, bureaucratic knowledge in the previous system becomes 'madness' which operates 'by itself' without referring to a decentred point (Zizek 2005) to symbolically justify its authority. As a result, such authority may not tolerate universal agencies which stand for justice, human rights or freedom of expression etc. or any other bodies which pass judgments about Law and Order. It would easily find an externalized 'enemy' or 'traitor' who conspires to 'steal' the essence of the nation (which it derives mostly from a nostalgic 
history). The gradual isolation, change in language policy, re-structuring the colonial education and governance (so called radicalization), policies to return to tradition and intolerance in criticism by external bodies are symptomatic political developments in such a context. The character Salim in the above mentioned $A$ Bend in the River, as a trader who travels into the interior African setting gradually experiences the stages of above developments. The attitudinal changes in the indigenous African characters such as Metty or Ferdinand in the wake of authoritarianism under nationalistic banner can be understood as 'unconscious obedience to the irrational call of the Master' (that of the Big Man falsely represented as the big Other; the Law); an element that is inherent in every human being. It shows the vulnerability of the subjective macho- sadistic drive within individuals that is successfully manipulated by the Master under such context.

There are two developments in the Third World that we either take lightly or completely for granted:

a. Unconsciously subjugating our daily life world into an unseen (mysterious) demand of the call of fundamentalism which ironically 'assures' that some untarnished history would be restored before us and would save us from the tension created by the present chaos.

b. Withdrawing from ideologically encountering this dangerous enemy who may finally 'steal' all the secular and rational inheritance of the postrenaissance humanity to the false luxury promised by consumer Capitalism.

Traditional societies are obviously caught in a whirlwind of fundamentalism, anti-secularism (while secular luxury is the demand of popular media every day) and blind obedience to tradition while they face grave changes in the tradition itself. There is no way out for them in this paradoxically positioned evolution of mutual antagonisms. Even those who were exposed to colonial 'education' could not completely overcome the irrational elements in the organic traditional societies. When such is elevated to indigenous politics, even 'the literate' succumb to irrational call of it.

For example, Ferdinand in $A$ Bend in the River becomes an administrator after his successful completion of school education but could never become 'universal' in his world view. In the beginning of the novel, as any mother in the post-colonial world who wants a better life for her son, Zabeth too wants Ferdinand to go to lycee as she wishes 'something better for her son' (41). She wants Ferdinand to go to school in the town and boarded in Salim's place because she thinks Salim being a foreigner and 'English speaking as well, someone from whom Ferdinand could learn manners and the ways of the outside world' (41). She prefers to keep her son with someone who is 'civilized' or at least knows how to be civilized. Zabeth wants her son to move 
away from the hard 'African life'.

It seemed to me natural that someone like Zabeth, living such a hard life, should want something better for her son. This better life lay outside the timeless ways of village and river. It lay in education and the acquiring of new skills; and for Zabeth, as for many Africans of her generation, education was something only foreigners could give (41).

The civilizing potential in education is illustrated where societies transform into advanced stages through higher cognitive levels achieved via education, which is always acquired with the help of an external otherness (often in the form of a foreigner from an advanced nation) who came from 'the west' especially during colonization. Here, Salim becomes a 'European agent' (despite his Indian- Caribbean origin) who speaks English and a spokesperson of European values. He could thereby easily establish a notion of some sort of ego-ideal for the natives in this part of the world, who dream to go beyond tribal boundaries.

Zabeth was aware of the civilizing potential within education in transforming individuals into civilized beings, breaking away from nature and the implication of its organic culture. The culture she belongs to is a primitive one and the way she protected herself from others too belongs to the organic nature of her primitiveness. The organic element of that society comprises of some 'essence' of primordial practices that passed onto the present individuals from traditional believes and ritualistic practices. For instance, Naipaul notices how Zabeth survived in the days- long river journey.

'She came and went with her vanity case and no one molested her...there was something else about Zabeth. She had a special smell. It was strong and unpleasant, and at first I thought- because she came from a fishing villagethat it was an old and deep smell of fish. Then I thought it had to do with her restricted village diet.... Metty said that Zabeth's smell was strong enough to keep mosquitoes away. I thought myself that it was this smell that kept men away from Zabeth.. ... but the smell was meant to keep people at a distance (10-11).

This is one good instance that explains how the 'organic cultural practices' operate in such communities where women use primordial methods to safeguard their womanhood from the seductive advances from a patriarchal social setting. When other women use perfumes to attract others, the kind of ointment that Zabeth uses disgusts herself despite, naturally, she is an attractive woman. The essence of that practice is the self-imposed 'worthlessness' of her existence and, in that case, such essence functions in a self-destructive manner. Woman's beauty becomes part of her personality and is always something that is commonly appreciated. In spite of individualism that 
promotes social mobility, 'the organic elements' of a primordial community function to patronize the fundamentalist masculine practices. This means that everyone silently and unquestioningly obey the blind ritualistic practices that are forced upon the individuals.

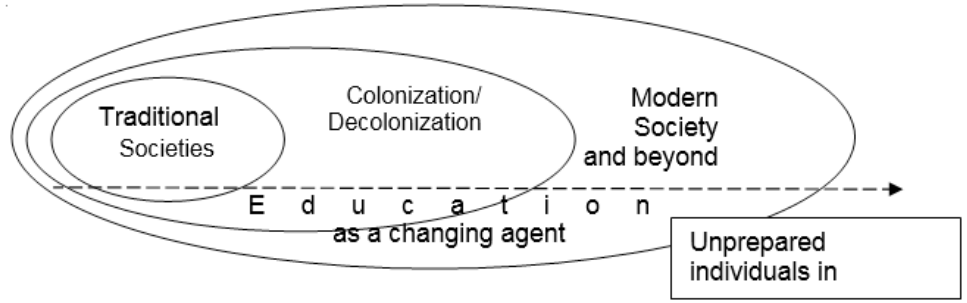

Figure 02: Function of education in social transformation

Source: Author

The above Figure 02 shows that education functions as a changing agent in transitional contexts but the traditional social remnants that are still prevalent in modern societies drive the individuals to the psychological comfort of tradition. The responsibility of the decolonization process is to establish and articulate a strong and vehemently rational system of secular education to change individuals to the complexities of modernity. When they are cognitively 'unprepared' to fully adapt to the new situation it may generate mental comfort zones where traditional justification legitimates their existence within the coordinates of modernity. While some socio-cultural elements (organic content) are also in a process of transition, such societies, mostly in the Third World, may not be ready to face modern secularism and its rational socio-cultural embodiments such as individualism, freedom and democracy. For this matter just reading and learning will not be enough. What is required is critical education which offers individuals an utmost freedom to question the existing ideologies and practices. For example, in A House for $\mathrm{Mr}$ Biswas, too the significance of education (termed as 'education frenzy') in a post-colonial context is highlighted as the children must be able to 'read' and 'learn', 'They still want their children to go to Port of Spain schools, and Mrs. Tulsi, fulfilling a duty that had been imposed in a different age... The cries of 'Read! Learn! increased' (Naipaul 2003: 463). Often, the feudal values and social frameworks in transitional societies suppress individual's authentic desire to interrogate the existing status quo, disagree and innovate by negation from the early stage of school education. The real tragedy in education is that those who were 'educated' finally succumb to the call of the totalitarian master and his irrational dehumanization. 
As I pointed out previously (page 05) totalitarian master seeks the obedience of the crowd by hystericizing them with a mixture of threat and promise. The nature of nationalization and radicalization that were introduced by the indigenous rulers during decolonization took place in the form of a threat and promise. As a wave of radical economic reformation influenced by the left-wing political developments during $60 \mathrm{~s}$ and $70 \mathrm{~s}$ in the third world, the income that nationalization produced was first channeled 'to expand the new middle classes' (Amin 1998: 32). On the other hand, nationalization always runs the risk in falling into the pitfall of 'national consciousness' which results from 'the intellectual laziness of the national middle class' (Fanon 1963: 149) when it defines it ideological justifications. Most dangerously, there are historical evidences that nationalistic motives have attempted to articulate the ethnocentric aspirations of a certain majority by over-determining the ethnic otherness as competitive enmity. Rather than universalization of humanism and respecting difference, it sets singular identity standards and generates dominant interpretations about the supremacy of the majority about the existing the life- world). With regard to the post-colonial plantation and land reforms in Sri Lanka, for example, as Oddavar Hollup observes, 'Land reform and nationalization of plantation must be analysed in connection with the emergence of Sinhala-Buddhist fundamentalist ideology and political patronage. The ideology, based on mytho-historical interpretations of the past, helped to create greater homogeneity by constructing a 'singular identity' among Sinhalas while at the same time excluding others (1998:84). However, as a Sri Lankan development of the above phenomenon of nationalism, substantial studies have been conducted over last twenty years (Roberts 2001; DeVotta 2007; Wijeyeratne 2014).

In the novel $A$ Bend in the River the nationalization mechanism was practised as an absolute radicalizing method of the existing status quo. As common to any 'totalizing' project of ethno-nationalistic nature, it excluded the 'foreigners'. The excluded felt that they do not belong there anymore. 'Nationalization: it had been a word. It was shocking to face it in this concrete way' (2002: 300). The so called 'revolution' which necessitates this kind of reformation is observed to be little 'rotten' (301) by the natives themselves. The rotten aspect of the systemic change (radicalization) is what made way to blind totalitarianism where foreigners were treated as a threat and forced to flee. As a result, their property (including land) and business pursuits were taken over by the government and granted the propriety to the locals where the original owners were asked to be under them. It says, as ordered by the President, 'And you will continue as managers' (301). The symptom of 'radicalization' which excludes ethnic otherness (the foreigners) was happing everywhere. Naipaul notices, 'What was happening to me was happening to every other foreign businessman' (246). The simple totalitarian principle behind this radicalization process is that, 'the President issued a statement, just to let 
everybody know that what Big Man gives the Big Man can take away. He gives and he takes back'(302). This means that everything belongs to the ruler. But the most cynical logic is that everything is taking place for the 'good of the majority' or according to the use of the egalitarian logic. As a result, the majority 'effectively' tolerates the functioning of the irrational logic and its violent application in their life-world. The reason why Ferdinand and Metty (and thousands of other locals) do not decisively oppose to the Big Man and his political manoeuvres in fundamentalizing and dissecting the true harmony of the society is that they are indirectly 'fascinated' by the unconscious fantasy to return to traditional hierarchy.

As extendedly shown in $A$ Bend in the River, the kind of ethnocentric 'nationalization' that was propagated across Africa was meant to take up every property that belonged to people of non-African origin or the traders from outside (like Salim) without rationally investigating how reasonably they traded with the African and how beneficial and efficient it would have been if they remained with them. What this process finally meant was under new political re-structuralization, every aspect of the life-world was influenced by the new 'unquestionable authority' which is the 'hidden truth of the discourse of the pre-modern masters' (Sharpe and Boucher 2010: 92). Finally, from the perspective of the victim, the functioning of the totalitarian symptom is displayed at its best when Salim's business was taken over by Theotime under the new system. 'It was strange. He wanted me to acknowledge him as his boss. At the same time he wanted me to take allowances for him as an uneducated man and an African. He wanted both my respect and my tolerance, even my compassion' (Naipaul 2002: 308). Salim was psychologically 'tortured' by the fact that he is 'supposed' to be there physically and witness the downfall of his own business through the (mis)management of an uneducated local. He is made to be present in a place which is 'actually' not his and is expected to be 'remorseful' to something that is actually alienated to him. The true nature of totalitarianism is that people need to pretend that they believe in the rotten system in power even though they don't. One has to act as if he or she does not recognize the true evil in the political body.

Another feature of fundamentalist totalitarianism is the anti-educational motive which prohibits critical thinking and questioning. This aspect is largely evident again in $A$ Bend in the River which reiterates, 'They are going to kill everybody who can read and write, everybody who ever puts on a jacket and tie' (322). Apart from the anti-Imperial resistance towards colonial education, there is an obvious element of 'returning to the pre-modern social primitivism' where things are forced to believe and practiced. In destroying the excluded ethnic other (whoever does not belong to certain dominant social group or community) one is granted a sadistic permission to violate all universal conventions about humanity and employ banality of evil upon the other. The 
novel clearly evidences that people outside to Naipaul's small circle in the Domain were not fully human who knows the 'worth of the other man' (136). People from other tribes are slaughtered like 'animals' according to premodern tribal believes which now go hand in hand with nationalistic slogan and anti-Imperialistic sentiments. 'They haven't done anything to you in jail. That's only because it hasn't occurred to them' (319). According to the above statement, Salim's life depends as long as how the locals feel about him not on whether he is right or wrong from a legal point of view. Irrespective of being a foreigner or an indigenous, one's actions must be judged by a neutral party with reasonable evidence. In this light of death of reason (which should be inculcated through education), the symbolic entity or the modern social order in the post-colonial world has seriously been damaged by the 'irrational call of the primordial master'.

\section{Conclusion}

In a context where Naipaul observes that the decolonization in this part of the world is full of chaos and disorder as shown mostly in The Mimic Men, In a Free State, A Bend in the River, whatever reforms that were originally intended ended up in utter failure. More than reason, traditional biases often become eminent in the socio-economic restructuring processes such as nationalization, radicalization or standardization in decolonization. Pre-modern social and cultural constructions such as tribal believe, ethnic boundaries, religious interpretations do play a major role in shaping the new life-world in these transitional societies. What is more problematic is due to these profound structural failures in the decolonization process, the symptoms of 'returning to the past', as displayed in Naipaul's works, drive the 'unprepared' decolonized subjects to subjugate themselves to the irrational call of the totalitarian masters who, within the co-ordinates of post-colonial mode of Liberal Capitalism, emerge from tradition itself.

\section{Endnotes}

1 The concept of 'decolonization' is a term used to signify the process of 'undoing' of colonialism. According to the Oxford Dictionary, decolonization is 'the withdrawal from its colonies of a colonial power, the acquisition of political or economic independence by such colonies'. The Oxford Companion to Politics of the World (2001 edited by Joel Krieger) defines decolonization as 'a change in sovereignty in which a state recognizes the independence of a segment of the people formerly under its rule' (193). 
2 A concept that theorizes the rebirth of policies of governance and economic activities and public and cultural life of individuals are restricted according to the remnant of feudal societies. For further insights, see Andreas Rahamatian's Copyright and Creativity: The Making of Property Rights in Creative Work (2011) 263.

3 Totalitarianism, in the context of this research, refers to the unconditional obedience to a regime which holds the total authority over the society and seeks to control all aspects of public and private life. Such body of authority is believed to 'fills the gap opened up by the modernist dissolution of all traditional organic social links'. Postmodernist also share the notion that such rise of totalitarianism is a 'necessary outcome of the modernist Enlightenment' (Sharpe and Boucher 2010: 88-89).

4 In the context of this paper, transitional societies are identified as ones which undergo serious socio-cultural dilemmas and challenges during the process of transforming from traditional forms (early modern, feudal or semi-feudal) to modern and postmodern forms. To slightly alter what Samuel P. Huntington observes in relation to post-Communist Central European contexts after the Cold-war, once the iron grip of the colonial Masters that kept all the conflicting interest groups together was either collapsed or released due to the pressure from indigenous politics in the mid $20^{\text {th }}$ Century, a violence crisis emerged within post-independent nations based largely on ethnic, religious and linguistic lines (Huntington 1993: 22). Most of these societies have undergone centuries of colonialism and now entertain independence but they still struggle to find out their own form and shape to face future. Most identifiable issues in these nations are fundamentally centralized among ethno-nationalistic, cultural and religious adaptabilities and problems in assimilation; therefore, the nature of their crisis is more ideological than material.

5 The concept of decolonization generally means 'the ending of colonialism and the liberation of the colonized' (Zag 2006: 20) by dismantling of the entire colonial government and it social system which exercise social control and exploitation of the indigenous communities.

6 Read the full article V.S. Naipaul: A Singular Writer by Maya Jaggi (also cited elsewhere in this study) published in the online edition of the Guardian posted on $8^{\text {th }}$ September 2001 http://www.theguardian.com/ education/2001/sep/08/artsandhumanities.highereducation. The author of this article compiles a critical account of Naipaul as how he broke away from the 'colonial shell' which helped him to become a more than a traveller but an inquirer. This objective and empirical inward journey is poignantly illustrated, for example, by Salim in the novel A Bend in the River (1979, 2002). 
7 In a contemporary Sri Lankan example, the former Rajapaksha regime was justified on a very superficial media claim that they derive from some historical hereditary. At the same time, President Rajapaksha is once called 'Maharaja' (the King), paradoxically a modern democratic ruler being elevated into some sublime level revisiting the pre-modern discourse, to give justification for his undemocratic movements after the Fourth Eelam War.

\section{References}

Arendt, H. (1951). The Origin of Totalitarianism. London. Harvest Books.

Ahmad, I. (2004). Imperialism of Our Time, in L. Panitch and C. Leys (ed) Socialist Register, London. Merlyn Press, pp 43-62.

Amin, S. (1994). The Future of Global Polarization, (Trans: Beatrice Wallenstein) in Development Research Series: Working Paper No 37, Denmark. Aalborg University, pp 1-11.

Amin, S. (1998). Capitalism in the Age of Globalization. London and New York. Zed Books.

Amin, S. (2012). The Arab Revolutions: A Year After, in M. Shihade, C.F. Fominaya and L Cox (ed), Interface: in A Journal for and about Social Movements. Vol.4. No. 01 pp 33-42.

Amin, S. (2013). Implosion of Contemporary Capitalism. New York. Monthly Review Press.

Amin, S. (2014) Samir Amin: Pioneer of the Rise of the South. USA. Springer. http://dx.doi.org/10.1007/978-3-319-01116-5

Assy, B. (1996). Eichmann, the Banality of Evil, and Thinking in Arnedt's Thought. Seminar Proceedings (Spring 1997) in the Department of Philosophy, New School for Social Research. Available online: https:// www.bu.edu/wcp/Papers/Cont/ContAssy.htm [accessed on 22nd June 2014]

Audi, R (1993).The Place of Religious Argument in a Free and Democratic Society. In San Diego Law Review (30). Pp 677-701

Benjamin, W. (1969). Theses on the Philosophy of History. in Illuminations (ed. Harry Zone). New York. Schocken Books. 
Bhabha, H.K. (1985). Signs taken for wonders: questions of ambivalence and authority under s tree outside Delhi, May 1817, in Francis Baker et al (eds) Europe and Its Others Vol. 1, Proceedings of the Essex Conference on the Sociology of Literature July 1984, Colchester: University of Essex, also Critical Inquiry. Vol 12, No. 01 (1985): 144-65. http://dx.doi. org/10.1086/448325

Bauman, Z. (2000). Liquid Modernity. London. Polity Press.

Bauman, Z. (2011). Liquid Modern Challenges to Education. Padova. Padova University Press.

Cader, R. (2008). V.S. Naipual: Homelessness and Exiled Identity. M.A. Dissertation in English, University of Stellenbosch.

Chakrabarty, D. (2000). Provincializing Europe: Postcolonial Thought and Historical Difference. Princeton. Princeton University Press.

Chakraborty, S. (2011). Space and Cultural Geography: A Study of V.S. Naipual's Representation of India in His Travel Narratives. $\mathrm{PhD}$ Dissertation submitted to the University of Burdwan, West Bengal. Calcutta.

Cudjoe, S.R. (1988). V.S. Naipaul: A Materialist Reading, USA. University of Massachusetts Press.

Deodat, R. (1979). V.S. Naipaul's Fiction, 1954-71: Fragmentation and Rootlessness. M.A. Dissertation, University of Guyana. Later published by Ottawa. National Library of Canada.

DeVotta, N. (2007). Sinhala Buddhist Nationalist Ideology: Implication for Politics and Conflict Resolution in Sri Lanka. Washington. East West Centre.

Dierckxsens, W. (2001), The Limits of Capitalism: An Approach to Globalization without Neoliberlaism. (Trans.Jayne Huchcroft). London. Zed Books.

Donghyun, K. (2011). Reason, Tradition, and Authority: A comparative study of Habermas and Gadamer, UK. University of Glasgow.

Dooley, G. (2006). V.S. Naipaul: Man and Writer. USA. University of South Carolina Press. 
Eid, H. (2000). Naipaul's Bend in the River and Neo-colonialism as Comparative Contexts in Comparative Literature and Culture. (Vol. 03; Issue 03). pp 2-12. Purdue University Press. Purdue.

Fanon, F. (1963). The Wretched of the Earth, (trans. Constance Farriongton). New York. Grove Press.

Feder, L. (2001) Naipaul's Truth: Making of a Writer, USA. Rowman and Littlefield Publishers.

Gadamer, H.G. (2006). Truth and Method. New York. Continuum.

Habermas, J. (2007). The Future of Human Nature, UK. Polity.

Habermas, J. (2006). Religion in the Public Sphere, in European Journal of Philosophy Vol 14: No 01. London. Polity, pp 1-25.

Habermas, J. (1981a). Modernity: An Unfinished Project, (also published under the title Modernity Verses Postmodernity) in New German Review (Winter 1981). USA. MIT Press.

Habermas, J. (1981b). Modernity Verses Postmodernity in New German Critique. Trans. Seyla Ben-Habib. No. 22, Winter, 1981). Pp 3-14.

Hardt, M. and Negri, A. (2000). Empire, USA. Harvard University Press.

Harode. R. (2012). Postcolonial chaos in V.S. Naipaul's Mimic Men. IRWLE. Vol, 8 No 1. Pp 1-8.

Hennayaka, N. (2006). Culture, Politics and Development in Postcolonial Sri Lanka. UK. Lexington Books.

Hollup, O. (1998). The Impact of Land Reforms, Rural Images, and the Nationalist Ideology on Plantation Tamils in Buddhist Fundamentalism and Minority Identities of Sri Lanka (ed. Tessa Bartholomeusz and Chandra R. De Silva). New York. State University of New York Press.

Huntington, S.P. (1996). The Clash of Civilizations and Remaking of World Order, New York, Simon and Schuster.

Jaggy. M. (2001). V.S. Naipaul: A Singular Writer. In The Guardian. Available online. http://www.theguardian.com/education/2001/sep/08/ artsandhumanities.highereducation. [Accessed on 10th April 2014]

Johnstone, R. (1979). Politics and V.S. Naipaul. Journal of Commonwealth Literature. XIV. Vol 1. Pp 100-108. 
Kellner, D. (2002) Theorizing Globalization, in Sociological Theory Vol.20, No. 3 (Nov. 2002), USA. American Psychological Association, pp 285305.

Krieger, J. (2001). The Oxford Companion to Politics of the World. United Kingdom. Oxford University Press.

Khan, M.A. (2009). Islamic Jihad: A Legacy of Forced Conversion, Imperialism and Slavery. USA. iUniverse.

Khan, T.A. (2012). The Post-Colonial State in the Era of Capitalist Globalization. New York. Routledge.

King, B. (2003). V.S. Naipaul. (2 ${ }^{\text {nd }}$ Edition). USA. Palgrave McMillan.

Marcuse, H. (1998). Technology, War and Fascism: Collected Paper of Herbert Marcuse (ed. Douglas Kellner). London and New York. Routledge. http:// dx.doi.org/10.4324/9780203208311

McLuhan, M. (2001). Medium is the Massage: An Inventory of Effects, California, Ginkgo Press Inc.

Miao, C. (2000). Transformative Learning and Social Transformation: A Cross Cultural Perspective. Toronto. National Library of Canda.

Mohan, C.R. (2004). Post-colonial Situation in the Novels of V.S. Naipaul, New Delhi. Atlantic Press.

Naipaul. V.S. (1967). A House for Mr. Biswas. Penguin. Middlesex.

Naipaul. V. S. (1967, 2002). The Mimic Men. Penguin. Middlesex.

Naipaul. V.S. (1971). In a Free State. Andre Deutsche. United Kingdom.

Naipaul. V.S. (1979, 2002). A Bend in the River, Picador, UK.

Noor, S. (2013). The futile struggle for self-determination in Naipaul's protagonists. Department of English and Humanities. Brac University. Bangladesh.

Paisley, F.\& Reid, K. (2014). Critical Perspectives on Colonialism. Writing the Empire from Below. New York. Routledge.

Park, J.S. (1996). An exploration of the outsider's role in selected works by Joseph Conrad, Malcolm Lowry, and V.S. Naipaul. PhD. Dissertation. Queen Mary and Westfield College, University of London. 
Rahamatian, A. (2011). Copyright and Creativity: The Making of Property Rights in Creative Work. UK. Edward Elgar Publishers. http://dx.doi. org/10.4337/9780857936332

Rawls, J (1997). Idea of Public Reason Revisited. In the University of Chicago Law Review, Vol.64-No 3. USA. University of Chicago Press. Pp 765807. http://dx.doi.org/10.2307/1600311

Roberts, M. (2007). Sinhala-ness and Sinhala Nationalism. Sri Lanka. Marga Institute.

Rutherford, D. (2006). The Cambridge Companion to Early Modern Philosophy. UK. Cambridge University Press. http://dx.doi.org/10.1017/ ccol0521822424

Said, E. (1986). The intellectual in the post-colonial world, 'Salmagundi' 79 (Spring-Summer, 1986). Pp 44-64.

Said, E. (1993). Culture and Imperialism. New York. Vintage Books.

Sharpe, M. and Boucher, G. (2010). Zizek and Politics: A Critical Introduction. UK. Edinburg University Press.

Singh, A. (2006). Literary Secularism: Religion and Modernity in Twentieth Century Fiction. UK. Cambridge Scholars Publishing.

Singh, B. (2013). Naipaul's India: A Million Mutinies Now: A Political Perspective. International Journal of Scientific and Research Publication. Vol.3: Issue. 1. Pp 1-3

Soyinka, W. (2009). Opera Wonyosi.

Stavrakakis, Y. (1999). Lacan and the Political. Blackwell. London.

Stiglitz, J. E. (2002). Globalization and Its Discontents. New York. W.W.Norton and Company. Inc.

Wallerstein, I. (1974). Dependence in an Independent World: The Limited Possibilities of Transformation within the Capitalist World Economy, in African Studies Review, Vol. 17, No. 1 (Apr., 1974), USA. African Studies Association, pp 1-26.

Wijeyeratne. R.S. (2014). Nation, Consitutionalism and Buddhism in Sri Lanka. New York. Routledge.

Zizek, S. (2014). Living in the End Times. London. Verso. 
Zizek, S. (2005). Interrogating the Real, Continuum, UK.

Zizek, S. (2008). Enjoy Your Symptom, Routledge, UK.

Zizek, S. (2002). For They Know Not What They Do: Enjoyment as a Political Factor, Verso, UK/USA.

Zizek, S. (2011). Did Someone Say Totalitarianism? Five Intervention in the (Mis)Use of a Notion. London. Verso.

Ziltener, P and Kunzler, D. (2013). Impact of Colonialism: A Research Survey, in Journal of World System Research, American Sociological Association. Vol.19. No.2. pp 290-311.

Zag, Z. (2006). Colonization and Decolonization: A Manuel for the Indigenous Liberation in $21^{\text {st }}$ Century. USA. Warrior Publications. 
